\title{
"Wat sal hierdie kindjie eendag word?" - Kindwees in die wêreld van Jesus (Deel 2)
}

P J J Botha

(Unisa)

\begin{abstract}
"What will this child become?" Childhood in the world of Jesus (Part 2)

This is the second part of an historical investigation into the conditions and experiences of childhood in first century Palestine. Aspects of early childhood, socialisation and education are discussed. The issue, "Jesus and the children" is explored briefly.
\end{abstract}

\section{INLEIDING}

Lukas laat ons met die indruk dat daar, na die merkwaardige gebeure rondom Johannes die Doper se naamgewing, die mense in die bergstreek van Judea gewonder het wat van die kindjie sou word (Luk $1: 66)$. Die bedoeling van die vraag is om heen te wys na bo-natuurlike dinge, na beloftes van God en ingrype van bowe, want normaalweg het mense nié gewonder wat van 'n kindjie sou word nie.

Destyds, soos reeds betoog in die voorafgaande deel van hierdie ondersoek ', is kinders en kindwees anders beskou as vandag. Kinderopvoeding was geskoei op ' $n$ androsentriese, patriargale lewenstyl. Met 'n kind se geboorte, het haar of sy familie deur een of twee beslissings die kind se hele lewe dramaties bepaal. Hierdie besluite is fundamenteel beïnvloed deur die siening dat kinders "onderworpe is", hulle word "besit". Mense se lewens en waardes is hierargies bepaal, gebaseer op "onbetwyfelbare" ongelykhede (cf Malina 1992:67-68).

Omdat die sterftesyfer onder babas en kinders so geweldig hoog was, is dit 'n geldige vermoede dat ouers destyds andersoortige (en dikwels nie te gou diepgaande) emosionele bande met hulle kinders gesmee het (Etienne 1977:152-54; Finley 1981:159; Golden 1988:159_ $60)$.

Verder, soos te wagte binne die antieke konteks, het kinders groot geword in 'n wêreld waar bose geeste en duiwels 'n voortdurende bedreiging was.

1 Kyk Skrif \& Kerk 20 (2) 1999:302-325. Ek beklemtoon weereens dat hierdie ondersoek ' $n$ inleiding tot en 'n verkenning van die problematiek van kindwees in Jesus se dae is. 
In wat volg, word aspekte van kinders se sosialisering en opvoeding in Jesus se dae bekyk. Die bedoeling is 'n bydrae tot die kontekstualisering en historiese verstaan van die Nuwe-Testamentiese geskrifte.

\section{KINDWEES}

\subsection{Die reinigingstyd soos deur die Wet van Moses bepaal}

'n Vrou was destyds, na die geboorte van haar kind, vir 'n paar dae onrein. Ons gebruik die woord "onrein" vandag, maar dit is moeilik om die emosionele en kulturele inhoude van die begrip destyds te beskryf. "Onrein" het niks te doen met "vuil" soos ons dit verstaan nie (higiëne). Die vrees was vir 'n soort psigiese of geestelike besmetting ("duiwels") en nie vir kieme nie.

"Onrein" het te doen met klassifikasie, met reg of verkeerd. Dit kon uitloop op verwydering van God af. Omdat die toestand van "onreinheid" onaanvaarbaar vir God was, het dit verreikende implikasies gehad vir die mense rondom jou, om van die effek op mens se eie lewe nie eers te praat nie.

Wanneer 'n vrou 'n seun in die wêreld gebring het, was die tydperk van moederlike onreinheid korter as vir 'n dogter (7 dae vir 'n seun en 14 dae vir 'n dogter). Gedurende dié tydperk mag sy nie aan haar man raak nie en ook nie aan mensgemaakte voorwerpe nie. Sy hou haar eenkant; haar kos en water word vir haar aangedra op 'n klipbord en klipbeker wat vir hierdie doeleindes in die huishouding aangehou word. Nog aan die begin van hierdie eeu is sulke vroue in Palestynse huise met 'n afskorting afgegrens van die res van die huis (vgl Granqvist 1947:44).

$\mathrm{Na}$ die tydperk van "volle onreinheid" het 'n langerige tydperk van gedeeltelike onreinheid gevolg. Ons weet dat hierdie opvattings belangrik was vir Joodse mense, maar presies hoe diegene op die platteland dit in die eerste eeu gedoen het, kan ons nie sê nie. Lukas probeer ons oortuig dat Maria en Josef besonder wetsgetroue Jode was - volgens die Fariseërs se voorskrifte - en dat die toepaslike reinigingsoffer in die tempel geoffer is. Dit is kan betwyfel word of ' $n$ arm Galilese egpaar werklik soveel erns met sulke voorskrifte sou maak, wat nog te sê van 'n duur uitgawe soos 'n reis na Jerusalem maak.

Wat ons wel weet, is dat ' $n$ kind van kleins af met rein of onrein te doen gehad het. Daar is twee implikasies van hierdie rein/onrein dualisme (vgl Malina 1981:122-51; Eilberg-Schwartz 1980:195-240) wat ons aandag verg ten opsigte van destydse kindwees. Eerstens was die vraag nie soseer wat 'n ding is nie, maar hoe dit is - aan watter kant pas dit in. So 'n vereenvoudigde interpretasieskema lei noodwendig tot 
'n obsessiewe kompulsie om te klassifiseer (soos die rabbis). Sodanige klassifikasie dra ook 'n finaliteit, 'n goddelike sanksie, wat onwrikbare onderdanigheid en aanvaarding verg.

Tweedens, het die klassifikasie rein/onrein 'n invloed op wat ouers hulle kinders leer. Vandag weerhou ons ons kinders van gevare (soos messe, elektrisiteit en hoë, smal mure). Die kinders in Jesus se wêreld is weerhou van "onrein" dinge. Die impak van 'n "rein-onrein"wêreldbeeld is om die werklikheid reg in te deel, en nie om te verstaan nie. Vereenvoudigd gestel: die verwagting was nie dat 'n kind ontwikkel nie, maar moes konformeer: daar bestaan met ander woorde reeds 'n duidelike, onbetwisbare gedragspatroon en die kind moet daarby inpas (vgl Cook 1978).

\section{2 ...julle wat nou honger het...}

In die Nuwe Testament vind ons slegs een verwysing na 'n historieskontemporêre hongersnood, naamlik die een in die dae van keiser Klaudius, tussen 44 en 48 (Hd 11:27-30, vergelyk Suetonius, Claudius 18.2; Tasitus, Annales 12.43; Dio Cassius, Hist 40.11). Hongersnode het egter met reëlmaat voorgekom, om-en-by elke 20 jaar (Hamel 1990:44-52). Graan (koring en gars of gort) het tot soveel as $70 \%$ van mense se daaglikse dieet uitgemaak en was altyd skaars (Forbes 1967:86; Broshi 1986:41-6). Oorproduksie in goeie jare kon net nooit genoeg bied om genoeg voedsel in slegte jare te lewer nie (Garnsey 1986:24). Ons kan bereken, op grond van vergelykende studies, dat die graanoes een maal elke vier jaar; die gortoes een maal elke twintig jaar en die peulgroentes drie uit elke vier jaar gefaal het. Neem nou in berekening die vervoertegnologie, moontlike stoorfasiliteite, politieke onstabiliteit en ander menslike faktore en ons besef dat selfs al sou hongersnood nie altyd voorgekom het nie, honger 'n alledaagse werklikheid was (Garnsey 1986:25).

In tye wanneer kos skaars was, het mense enigiets bymekaar gemaak: voëleiers, insekte, blare van sommige plante. Gegewe die waardes van destyds was kinders die eerstes om te ly as gevolg van hongersnood en plae (Malina \& Rohrbaugh 1992:117-18). Ouer mense - en dan veral die volwasse getroude mans - het eerste kos gekry, en daarna die jong vroue en kinders.

Wanvoeding was 'n alledaagse verskynsel. Vanuit 'n dieetkundige hoek bekyk, was tipiese diëte destyds ontoereikend. Alhoewel groente volop was en op meeste tafels verskyn het, was dit allerweë beskou as armmanskos. Vleis is selde geëet. Dit is wel deur die meeste intens begeer, en was 'n voedselsoort met kragtige emosionele en politieke konnotasies (Fiddes 1991; Hamel 1990:25-29; Detienne \& Vernant 1989). Gemufte deeg en brood is gereeld verorber en beskou as kos vir 
kinders. Rabbynse bronne vermeld hoedat kinders, wanneer die geleentheid hom voorgedoen het, hulle vergryp het aan vrugte en geroosterde koring (m.Baba Mesia 4.12; p.Berakhot 2.7.5c; b.Pesahim 109a). Beide Augustinus en Hieronimus was diep ontstemd oor herinneringe van onbeheerbare honger in hulle kinderdae (Brown 1967:36-7; Kelly 1975:8-9).

Dit is moontlik dat antieke mense se beheptheid met toestande van veluitslae en velkwale saamhang met die algemeenheid daarvan weens wanvoeding (cf Sussman 1992). Sodanige toestande moes die gesondheid van jongmense en veral kinders ernstig geraak het - veral dan die feit dat hulle kos dikwels te min was, en meesal ongebalanseerd wat betref voedingsinhoude.

Opvallend in hierdie verband is hoedat Rabbi Hanin Deuteronomium 28:66 uitlê:

"Jou lewe sal aan ' $n$ draadjie hang: dit is die man wat koring vir die jaar bymekaar gemaak het. Jy sal dag en nag in vrees lewe: dit is hy wat koring by die smous koop. Jy sal jou lewe lank onveilig wees: dit is hy wat brood by die bakker [op straat] moet koop" (p.Sheqalim 8.1.51a; p.Shabbat 8.11a).

Dit is heeltemal te verstane dat die volksmond sou kon sê dat "terwyl die vette maer word, is die een wat maer is klaar dood" (cf Hamel 1990:55).

\section{3 ...kinders wat op die markpleine sit en fluit en roep...}

Stad, dorp of plaas, moderne of antieke wêreld - kinders het nog altyd gespeel. In Galilea het kinders groot geword in 'n agrariese ekonomie, en kinders wat saam met hulle moeders "veld" toe gegaan het, het daar gespeel terwyl gewerk moes word (cf Whiting \& Edwards 1988:2730 ). In die geheel gesien egter, was daar nie veel tyd vir die kinders om te speel nie. Kleinboergemeenskappe beskou kleintjies wat gespeen is maar nog jonger is as sowat drie jaar oud as "babas" en word nie alleen gelaat nie (cf Bloch \& Adler 1994:163-64). Die ouer dogters van die familie/huishouding is verantwoordelik vir hierdie kinders. Maar as hulle so vier tot vyf jaar oud word, word kinders al meer vrye beweging binne die grense van die dorpie toegelaat en oorgelaat aan die toesig van die gemeenskap. Dit is van hierdie stadium af wat daar van hulle verwag word om deel te neem aan die familie se werksaamhede. Families het kinders gesien as bronne van arbeid en inkomste. "Speel" word van kleinsaf geïntegreer met "werk" en "opleiding" (Bloch \& Adler 1994:151-57). 
Vrye spel is geassosieer met kleintjies wat nog nie sonder ouer toesig gelaat word nie - dit wil sê, met kleuters. Die gevolg is dat georganiseerde speletjies relatief min voorkom in sulke gemeenskappe (vgl Fuller 1961:40). In agrariese kulture is kinders baie meer deel van beheerde aktiwiteite (dit wil sê werk) as van vrye aktiwiteite “'directed' activities (work) vs 'undirected' activities, which include play" (Bloch \& Adler 1994:150). Nie dat kinders nie vermaak gehad het nie; dit was net dieselfde as dié van die ouer geslag.

"From the time they are infants in arms, they accompany grownups to an evening of storytelling or to a wedding or other gathering. Because of this close sharing in the adult world of entertainment, there is little incentive or opportunity to build a separate children's world apart. Not possessing a separate world or personal solitude, village children lack fantasy, imagination, and personal creativity. This lack of individual imagination is found among adults as well and helps permit the tradition to crystallize and continue" (Fuller 1961:40).

Waarmee het kinders gespeel? Ons weet besonder min van die speelgoed en kinderspeletjies van eerste-eeuse Galilea. Die kinderspeelgoed wat ons wel iets van weet (as gevolg van opgrawings en so meer) kom meesal uit welaf, voorstedelike (Grieks-Romeinse) huishoudings. In verband met speel en speelgoed van die destydse Mediterreense wêreld (cf Leyerle 1997:251-53; Veyne 1987:14-5) noem ek die volgende: Poppies met beweegbare ledemate was gewild - blykbaar ewe veel onder seuns en dogters - en is meesal van klei (terra cota) gemaak. Dogters het ook poppe van stokkies en lap gemaak - om aan grootmense te vertoon en nie soseer om mee te speel nie. Poppe het grootmense voorgestel. 'n Griekse pa spog as volg oor sy seun:

"Moenie bekommerd wees nie: leer hom net! Hy is eintlik baie slim. Hy was skaars 'n handbreedte hoog toe het hy al huisies van klei, bootjies van hout, en sleepwaens uit stukkies leer gemaak. Hy het ook granate gekerf om soos paddatjies te lyk! Jy sal nie glo hoe oulik nie!"2

Ons weet dat verskeie vorme van bordspeletjies gespeel is. Mehen was welbekend, en mehen-borde is in Egipte, Lebanon, Sirië, Siprus, Kreta

\footnotetext{
2 Dit is 'n "fiktiewe" pa, Strepsiades, wat probeer om Sokrates gerus te stel dat die seun, Feidippides, goed genoeg is om die kuns van retoriese argumentasie aan te leer; Aristofanes Wolke 877-880.
} 
en Qumran gevind (Levy 1998:22). Hierdie (meesal van klip) borde het 'n patroon opgehad met nommers en merke in 'n spiraal gerangskik. Meeste van die speletjies waarvan ons weet, is natuurlik deur grootmense gespeel, maar vermoedelik het kinders (meesal seuns, waarskynlik) vroeg die tegnieke en reëls aangeleer.

Dobbelspeletjies (gooi van gemerkte voorwerpe wat "ewekansig" bepaal wie wen) was baie gewild. Die spintol is ook baie deur kinders benut. Eweeens is blinde-mol dikwels deur kinders gespeel.

Kinders van alle tye boots dinge na wat groot mense doen: mans wat dans op ' $n$ troue (seuns wat op die fluit speel, maar dan wil die maats nie dans nie - Matt 11:17) en vroue wat rou by 'n begrafnis (dogters wat ' $n$ treurlied sing, maar hulle maats wil nie saam skree nie - Matt 11:18). Ons kan vermoed dat daar ook balspeletjies was (met enige ronde voorwerp; miskien 'n houtbal maar meesal met 'n opgestopte stuk lap of leer). Stokke en klippe maak maklik speelgoed.

Alhoewel speletjies soms vernuf en atletiese vermoëns vereis het, was die meeste speletjies ' $n$ weerspieëling van die mense se kultuur: dit is nie hul prestasies wat hul die wenners mak nie, maar "geluk" (die geheime magte, die wil van die gode, die keuse van God) beslis mense se posisie. Dit was ook 'n tyd waar die verloorders eerder gekasty is as wat wenners vereer is.

Jong seuns van die dorpie werk dikwels as skaapherders. Hulle mak slingervelle - eintlik weef hulle dit - en is baie gou baie akkuraat daarmee. Skape wat afdwaal, word aangekeer en voëls word gejag.

Stories is nie met slaaptyd vertel nie, maar met aandetes. Lang stories is in aflewerings oor ' $n$ paar aande vertel (Leyerle 1997:255).

\subsection{Gegroei en sterk geword...}

Kinderarbeid was destyds die norm (cf Bradley 1985; Shahar 1990: 243-44). ' $n$ Kind se ontwikkeling is nie gemeet in jare nie, maar in vermoëns (Falk 1974:508-09; Bradley 1985:329; cf Bloch \& Adler 1994:151-52). 'n Eerste fase is wanneer 'n seun diere kan wegjaag van die tuine af. Dan kan hy ' $n$ bokherder wees - twee of drie bokke word gewoonlik in die binnehof (courtyard) aangehou. Daarna word hy as ' $n$ skaapwagter ingespan ('n troppie diere word aan hom toevertrou). Van die middel van die somer tot laat herfs help hy met die druiwe, olywe en (somer-)vye oes. Ploeg is manswerk, en ouer seuns en jongmans word daarby betrek. 'n Jongman kan ook wapens dra en gevorderde vaardighede aanleer: die versorging van gereedskap, instandhouding en so meer.

Die ontwikkeling van dogters volg 'n ander weg. Trouens, mens moet eintlik nie van "kinders" in Jesus se tyd praat nie; gegewe die 
belang van geslagsonderskeiding wat destyds gegeld het, moet ons konsekwent na seuns en dogters verwys. Dogters het baie gou bewus geword daarvan dat hulle lewens gerig is op die huis en kinders en dat daar inderdaad ' $n$ groot verskil bestaan tussen hulle en hulle broers en neefs (Archer 1990:70-101; Fuller 1961:37; Malina 1996:105).

Van die eerste take wat dogters moes verrig, is om die hoenders weg te jaag (die binnehof word tussen mense en diere gedeel: veral hoenders, 'n paar bokke, 'n donkie of twee). Van so vyf jaar oud af (min of meer) begin sy brood bak; verder soek sy vuurmakhout en dra water aan. Skottelgoedwas is meisiewerk. Soos wat sy ouer word, neem sy meer en meer van die verpligtinge van die pluimvee (wat ook duiwe insluit) oor. Verder moet die dogters sorg dat die beddegoed gebêre word en die vertrekke van die huis asook die binnehof uitgevee word. En dan natuurlik moet die (jonger) kinders opgepas word.

Meisies word ook gou betrek by "veldwerk": gras (vir dakke, vuurmaak, besems, en kos) moet versamel word, asook veldgroentes. Die jong dogters se tipiese dag was hoofsaaklik een van harde werk. Hulle oggend het met water aandra begin, en in die aand was dit weereens so. $\mathrm{Na}$ 'n begrafnis, of na 'n feesgeleentheid ('n huwelik), herdenkingsmaaltyd (die dooies is vereer met ' $n$ jaarlikse feesgeleentheid), is alle waterhouers leeggemaak en met vars water gevul. "In short the work of a growing girl is grown-up woman's work in miniature" (Granqvist 1947:139).

Teen so nege jaar oud (of selfs jonger) het 'n meisie se voorbereiding vir die huwelik in alle erns begin; sy is meer en meer eenkant gehou en die ander vroue in die huishouding het begin om doelbewus daarop te konsentreer om seker te maak sy sou weet wat om te doen as moeder en huisvrou.

Seuns het vanaf hul vyfde jaar begin help wanneer daar geoes moes word. Seuns en volwasse vroue was verantwoordelik vir die meeste oeswerk, en seuns was meesal verantwoordelik vir die pluk van olywe, vye en druiwe. Die jaar het, wat die groot werk betref, in twee uiteengeval: middel-Oktober tot Maart vir ploeg en saai; vanaf einde Maart word geoes, bymekaargemaak, gedors, verwerk en gestoor (cf Bimson et al 1985:66). Die reël van die lewe was eenvoudig: laat nóu slap lê en jy krepeer van die honger in die winter.

Tussendeur moes landerye opgepas word. Die groot grondbesitters het 'n man (of 'n paar mans) gehuur om dit te doen; die meeste ander families het die ouer seuns hiervoor laat beurte neem.

Klein kinders moes in die algemeen uit die pad van die volwasse mans bly. Hulle het eenkant geëet, en was altyd naby 'n moeder en ander vroue. Die grootmak van kinders was, vir alle praktiese doeleindes, vroue se werk. 
In die aande het kleuters, kinders en ongetroude jongmense slaapgeriewe gedeel (Hirschfeld 1995:275-6). Siek kinders is nie apart gehou nie; trouens hulle het soos gewoonweg beddegoed en skottelgoed met die res van die familie gedeel. Buiktifus en disenterie het daarom dikwels soos 'n veldbrand onder kinders versprei (Canaan 1927:180).

Omdat kinders op mekaar aangewese was, het hegte bande ontwikkel. 'n Meisie se beste vriend was gewoonlik haar naaste broer - 'n band wat hulle sou saambind vir die res van hulle lewens. As volwassenes was twee getroudes selde vriende; 'n vrou sou eerder haar broer(s) nader om 'n probleem met haar man te probeer oplos.

Seuns wat min-of-meer in dieselfde jaar gebore is (met ander woorde, tot so twee jaar uit mekaar) het groepe gevorm wat lewenslank vriende bly.

\subsection{Kleredrag}

Spesifieke kinderdrag het nie eintlik bestaan nie. Kinders se klere was maar dieselfde as dié van grootmense. Met verwysing na die kleding van die dogters van Palestynse kleinboere aan die begin van hierdie eeu vermeld Granqvist (1947:125) dat "[t]hey look like grown-up women in miniature" (meer oor kleredrag destyds: Botha 1998:18-21).

'n Kind het 'n eenvoudige, reghoekige kleed oor die skouers gedra wat om die middel vasgebind is. Wat ons vandag onderklere noem het nie destyds bestaan nie; ' $n$ soort van lendekleedjie om die middellyf is as voldoende beskou. 'n Meisie se "lyfrok" is herstel en groter gemaak so lank as wat dit enigsins moontlik was. Eers met puberteit en huwelik is ' $n$ behoorlike stel klere vir haar gegee. Kinders het kaalvoet geloop; 'n paar sandale het gewoonlik deel geword van hulle uitrusting in die maande voor of tydens verlowing.

Vir seuns is soms 'n lyfrok gemaak volgens die patroon van 'n hemp. Die meeste mense het in elk geval net twee kledingstukke besit (om een daarvan weg te gee soos Johannes die Doper verwag het, was dus nogal veel gevra). So kosbaar was klere, dat die rabbis lang debatte gevoer het oor watter klere op 'n Sabbatdag gered sou kon word indien jou huis afbrand.

\section{OPVOEDING}

Die siening van opvoeding was destyds dat 'n kind gevorm moes word (Faber van der Meulen 1996; Pilch 1993:104-05). Om 'n kind te laat "ontwikkel" en aan te moedig om nie net nuwe dinge te ontdek nie maar ook die kind se eie potensiaal, was ongehoord; kinders moes 
ingeperk, getugtig en gevorm word (soos 'n ruwe stuk hout wat met mag en mening afgewerk en weggeskaaf en glad gemaak word).

'n Kind het destyds groot geword binne 'n klein, geïsoleerde, nieliterêre gemeenskap wat kultureel én biologies besonder homogeen was en wat ' $n$ oordrewe klem op solidariteit geplaas het (vir die teoretiese begronding van hierdie interpretasic: Redfield 1947; Lutfiyya 1966: 168-87). Tipiese gedrag binne so 'n groep is "traditional, spontaneous, and uncritical" (Redfield 1947:297), dit wil sê, wat een persoon doen is baie dieselfde as wat die volgende persoon doen.

\subsection{By die huis}

In die antieke wêreld, en veral op die platteland, was daar nie juis skole nie, en kinders se opvoeding was 'n huishoudelike taak. Babas bring uiteraard die meeste tyd in moederhande deur, al was vaders nie ongeneë om 'n baba rond te dra of vas te hou nie. Maar, naas 'n kind se moeder is dit oumas en oupas wat die meeste met kinders te doen gehad het. Van kleins af word die kleintjies in die sorg van grootouers gelaat. In die nag sal 'n oupa of 'n ouma maklik 'n kleintjie in hulle arms laat slaap. As gevolg van hierdie noue bande tussen kleinkinders en grootouers word 'n konserwatiewe en tradisionele uitkyk op die lewe by die kinders gevestig; van kleins af word die kinders se wêreldbeeld gevorm deur 'n verbygaande geslag (Fuller 1961:37).

Opvoeding is 'n sosiale meganisme wat mense vorm om te wees wat hulle samelewing verwag. Joodse meisies het nie 'n gelykwaardige opvoeding met demokratiese waardes ontvang nie. So 'n opvoeding sou hulle vreemdelinge in hulle gemeenskap gemaak het. Die rolle, take en verwagtings van vroue was beperk en doelbewus as sodanig gehandhaaf: sy moes 'n moeder en huishoudster word.

"At home women read little; perhaps few were literate. But songs and superstitions, stories, old wives' tales, and medical magic, and everything pertaining to religion which did not require detailed scriptural knowledge was their domain; the culture, though nominally controlled and propagated by males, who alone took to book learning, was actually carried in the mores and the uneducated traditions of the females" (Derrett 1973:32-33).

Die rol van ' $n$ pa in die sosialisering van sy kinders was minimaal. Enersyds was hy dikwels weg; nie net vir daaglikse werk in die omgewing nie, mans het dikwels vir lang tye op ander plekke gaan werk: op die groot plase of in die nabygeleë dorpe. Vaders het hulle dogters eintlik nie baie goed geken nie; hulle het bitter min met dogters te doen gehad. Meeste vaders was in elk geval al oorlede teen die tyd wat hulle 
kinders hulle tienerjare bereik. Ons weet dat twee uit drie kinders 'n ouer verloor het alvorens hulle puberteit bereik het, en dan enkele jare later die ander een.

Die uitsondering wat betref vaderlike aandag, was lyfstraf. Dit was 'n wêreld waar "liefde" en die roede een en dieselfde ding was. "Buig sy nek en slaan hom behoorlik terwyl hy jonk is" het die spreekwoord gesê (Sirag 30:1-13, spesifiek vers 12. Kyk ook Spr 13:24, $22: 15,23: 13-14,29: 15,19)$. Kinderlike gehoorsaamheid in Jesus se wêreld was geen ligtelike sakie nie, met verreikende psigiese en sosiale implikasies (Pilch 1993; Barr 1988; Malina 1996:67-96). Ouer kinders, en veral ouer seuns, het nogal goed deurgeloop (Safrai 1976:770-1; Veyne 1987:16-7). 'n Tipering van ouer-kind verhoudings, om Shahar (1990: 252) se woorde te gebruik, moes waarskynlik so gelyk het:

"There is no room for idealization in assessing relations between parents and children in peasant society. The lives of peasants were hard, and there were wretched people among them, and the wretched are not necessarily tender and affectionate towards those close to them. Violence existed among the peasantry, as it did in other... strata... Yet, as in every other society, parents undoubtedly differed in their treatment of their children."

In die Joodse wêreld was opvoeding nasionalisties en eksklusief. Joodse mense het hulleself as 'n volk wat eenkant is, beskou en hulle kinders is so groot gemaak. Slegs hul eie geskiedenis, tradisies en gebruike is aan kinders geleer. Dit is belangrik om te besef dat die mense nie hulle tradisies "bestudeer" het nie. Bestudeer veronderstel 'n kritiese ingesteldheid: dit behels vrae soos hoekom en waarom en kan dit nie dalk anders nie. In daardie wêreld was dit voldoende om te sê: "Hoor wat daar van die ou tyd af aan die mense gesê is..." (Mt 5). Wat die ouers en voorouers gesê het, was waarheid. Die basiese reël wat betref antieke opvoeding is waarneming en nabootsing. Hou die grootmense dop en doen soos hulle doen!

Die kennis en gebruike van ander mense is by voorbaat afgemaak as "heidens", "onrein" en nutteloos. Godsdienstige tradisies was 'n belangrike element in kinders se opvoeding. Seuns is direk daarin onderrig, dogters indirek. Die meeste voorbereiding is egter gewy aan die dinge wat nodig is om 'n suksesvolle en produktiewe lid van die huishouding te wees, veral wat dogters betref. Hulle is geleer hoe om kos te versamel en te verwerk, hoe om wol te spin en te weef. Weefkuns was belangrik, omdat materiaal so belangrik was. Klere is binne die huishouding vervaardig, en van kleinsaf is mense hiervoor voorberei. 
Meer intelligente kinders is ook die fyner kunsies van voorspelling (waarsêerskuns) en die interpretasie van voorbodes en drome geleer. Volksmedisyne was belangrik vir dogters omdat siektes so 'n algemene verskynsel in elke huis was, wat binne die bestek van vrouepligte geval het.

Kinders is geleer om nie nuuskierig te wees nie. Nuuskierigheid was dieselfde as dwaasheid; dit lei jou gedagtes weg van jou pligte. Alles is tog soos God dit gemaak het, en net 'n dwaas wil weet hoekom. Wysheid is om fatalisties die dinge soos dit is te aanskou. Ons kan selfs sê dat fatalisme dié kenmerk is van mense van destyds.

\section{2 'n Skryfbordjie en skryf daarop...}

Lees en skryf was vir die oorgrote meerderheid mense nie belangrik nie. Wie wou of kon tyd mors op so iets? Daar was in elk geval 'n "dorpsklerk" wat al die skryfwerk en leeswerk wat nodig was, gedoen het, veral op die plattelandse dorpies. 'n Meisie moes kon tel, en eenvoudige optel en aftrek somme kon doen. Seuns, wat as mans meer met die openbare lewe te doen sou kry, is soms die belangrikste letters geleer. Kinders is grootgemaak om 'n spesifieke wêreld te verstaan en te beleef: eerstens die familie, tweedens die dorpie. Daar is doelbewus gestreef om geslote gemeenskappies te handhaaf.

Lees en skryf was egter vir sommiges 'n loopbaan, en jong mans kon vakleerlinge van die skryfkuns word. Een van die (baie) redes hoekom lees en skryf nie prominent was nie, was die gebrek aan skryfmateriaal. Trouens, 'n belangrike aspek van 'n Skrifgeleerde se werk - wanneer hy ${ }^{3}$ nie skryf nie - was om die nodige skryfmateriaal voor te berei. As "spesialis" in die skryfkuns het hy self die diervelle vir belangrike geskrifte voorberei en moes hy die "papier" vir ander geleenthede voorsien. Ook sy skryfstif (of stilus) moes hy maak en self sy ink meng. Een van die redes hoekom kinders nie die skryfkuns geleer is nie, was juis omdat die voorbereiding van die skryfmateriale nie aan kinders toevertrou kon word nie (skerp messe, duur ink, baie duur papirus). Gewoonlik het mense wat wel leer skryf het, so vanaf hul dertiende tot vyftiende jaar daarmee begin (Demsky 1988:1-7; Lewis 1974:30-40). Die bietjie onderrig in leestegnieke wat kinders aangeleer het, moet ons eerder beskryf as 'n soort syferkennis

3 Daar is enkele aanduidings dat daar wel vroue scribes was in die Romeinse wêreld, en meisies wat as kalligrawe gewerk het, het moontlik selfs van die NT manuskripte gekopieër (Haines-Eitzen 1998), maar ek twyfel of daar in die "Joodse" wêreld uitsonderings op die reël dat net mans skrifgeleerdes geword het, was; vergelyk Crenshaw 1998:168-169, 179. 
(numeracy). Die gevolg is dat selfs diegene wat 'n paar woorde kon lees, nie noodwendig kon skryf nie.

Wat van skoolgaan? Ons, westerlinge, sien skool as so 'n integrale deel van "normale" lewe dat dit baie moeilik is - veral vir geleerde navorsers - om te begryp dat antieke "skole" 'n totaal ander wêreld reflekteer. Die destydse wêreld was, om van Philippe Ariês se woorde gebruik te maak, 'n wêreld met "no idea of education" (Ariès 1996: 395); dit wil sê, opvoeding wat deur 'n volwaardige en selfstandige instelling met eksplisiete funksies bedryf is, het nie juis bestaan nie.

In die antieke wêreld was daar nie iets soos wat ons vandag ken as openbare skole nie. Om te beweer dat sinagoges "skole" was, is om ons sienings anakronisties terug te projekteer. Wat sou kinders in so 'n skool geleer het? Wat sou hulle met hulle skoolkwalifikasies gedoen het? Selfs al sou 'n "sinagoge" 'n "skool" (vir lees en skryf) gebied het, moet ons dit as 'n deel van daardie wêreld voorstel. Wanneer daar werk was, kon daar nie skool gewees het nie: oes, ploeg, saai, is gemeenskapstake wat voorkeur moes kry. Of dink aan die "onderwyser": hoe is hy opgelei en waar het hy voorberei? Dit is juis in die klein dingetjies wat mens die verskille besef. Byvoorbeeld, as gaste opdaag by die "onderwyser", het hy eers sy verpligtinge teenoor hulle nagekom en is "skool" vir etlike dae gesluit. Immers, belangrike dinge eerste!

Dit is insiggewend om Granqvist (1947:143-151) se verslag oor sulke dorpskooljies onder Mediterreense kleinboere (aan die begin van hierdie eeu) te lees. "School has no real roots in the consciousness of these people" (Granqvist 1947:150; Botha 1992, 1993).

In die destydse perspektief was daar altyd iets belangriker as "studeer": familie, werk, selfs die weer. Dan moet daar ook in ag geneem word dat betaling ter sprake was, dat daar 'n algehele gebrek aan boeke was en dat iemand se binnehof, 'n deel van die dorpsplein of 'n paar bome buite die dorp moes dien as skoolterrein.

\section{3 "Wat sal hierdie kindjie eendag word?"}

Familie en God domineer die gemeenskap en die individu. Volgens die waardes van destyds was die reputasie van die familie sentraal. Mense het anders as vandag oor hulleself gedink: die ideaal was nie om selfvervulling en persoonlike geluk te vind nie. Meer korrek: selfvervulling en geluk was geleè in die status, eer en reputasie van die familie.

Die sosialisering van die kind was sodanig dat identiteit in terme van sy/haar familie beleef is. Lojaliteit is altyd toegespits op vader, broers, moeder, susters. Hierdie lojaliteit strek van die gesin na die familie na die dorp (waar almal in elk geval aan mekaar verwant is) waarbinne die kind groot word. 
'n Dogter aanvaar gou dat die lewe gerig is op seuns. Alles rondom haar herinner en versterk en "bewys" hierdie "gegewene". As sy en haar broer gaan hout optel, dra sy die bondel; as haar boetie die waterskottel omstamp, maak sy skoon; as hulle tussen volwasse mans beland, loop sy agter; hý en nie sy nie kry die laaste porsie kos of lekkerny. Wanneer sy groot is, dra sy die bagasie, handelsware en kos terwyl haar man op die donkie sit.

"The education of the girl is an apprenticeship in the superiority of the male, and in the necessity to prepare herself to accept, throughout her whole existence, the harsh constraints which nature, men and God himself have decreed for her" (Bouhdiba 1977:131).

Vir seuns was die oorgang na die manswêreld toe 'n traumatiese gebeurtenis. Eenklaps moes hulle 'n hele leefwyse (saam met moeders en vroue) verwerp en as "mans" optree.

Jongmans het destyds nie vir 'n maatskappy of 'n firma gaan werk nie, maar vir 'n ander familie. Daar het jy altyd harder gewerk as die seuns van daardie familie en altyd minder verdien. Vakleerlingskappe het begin in die dertiende tot vyftiende lewensjaar. Die besluit oor watter vaardigheid of werk was geheel-en-al in die hande van die volwassenes.

'n Vakleerlingskap het sowat vier tot vyf jaar geduur, en was gewoonlik by ' $n$ broer of neef van die kind se pa. Die omstandighede ten tye hiervan was maar swaar: daar is van sonsopkoms tot sonsondergang gewerk, sonder betaling vir die eerste twee of drie jaar. Dan is 'n maandelikse fooi ontvang. Vir die eerste twee jaar is net kos en klere aan die leerling gegee (sien byvoorbeeld, Papirus Oxyrynchus 725 Hunt \& Edgar 1932 no 14). Seuns en dogters het wewers geword, seuns het ook spykermakers, musiekinstrumentmakers, bouers, houtwerkers, Skrifgeleerdes en kopersmede geword.

\section{JESUS EN DIE KINDERS}

Uiteraard kom die vraag by mens op, wat van Jesus en die kinders rondom hom? 'n Paar uiterstes moet vermy word in enige sodanige bespreking. Enersyds, om Jesus se sogenaamde verhouding met en opvattings oor kinders te romantiseer (Dit is baie belangrik om te beklemtoon dat Jesus self ' $n$ kind was van sy tyd). Andersyds, moet ons die berigte oor Jesus se interaksie of verhoudings met kinders lees vir wat die berigte self wil kommunikeer. Die Evangelies is nie psigologiese handboeke of historiese verslae nie, maar verhale wat daarop gerig is om die lesers oor te haal na 'n (antieke) lewensstyl en 
geloofsperspektief. In 'n sekere sin is dit dus korrek om te beklemtoon dat die beriggies oor "Jesus en die kinders" primêr bedoel is as "teologie" - as metafore vir die ware kerk of vir egte geloof.

Dit is (verbasend) moeilik om 'n sinvolle oorsig oor die vraagstuk "Jesus en die kinders" te gee. Daar is maar enkele Nuwe-Testamentiese tekste wat Jesus en kinders in verband met mekaar bring 4 . Hierdie tekste is moeilik om te interpreteer. Hulle preek egter lekker, want allerlei aantreklike veralgemenings kan daaraan gekoppel word.

Die evangelieskrywers het elkeen die Jesustradisies op unieke wyses gekontekstualiseer. Volgens hulle het Jesus, telkens wanneer hy met kinders te doen gehad het, met sy dissipels gepraat en húlle onderrig. Die evangelieberigte oor Jesus en die kinders is deur volwasse mans geskryf en is bedoel as boodskappe vir volwassenes (meesal mans, weereens).

Ek dink nie dat dit moontlik is om 'n afleiding te maak soos "Jesus had a fully realistic view of children" soos wat byvoorbeeld Weber (1979:13) doen nie. Jesus was nie getroud nie, hy het nooit kinders groot gemaak nie; hy het na alle waarskynlikheid traumatiese kinderjare gehad en hy het maar min gedink van sy eie familie. Jesus het ook 'n baie sterk eindtydsverwagting gehad. Die basis vir Weber se stelling is die Evangelies se verslag dat Jesus gesien het hoe kinders speel. En dit is al wat die teks sê: dat Jesus kinders se poging om te speel beskou as 'n goeie illustrasie van om iets te probeer wat nie uitwerk nie. Beide Matteus en Lukas maak van Jesus se opmerking oor die kinders wat speel, laasgenoemdes tot voorbeelde van wat 'n dissipel nie moet wees nie: "hierdie geslag" (die Fariseërs, diegene wat Jesus nie wil aanvaar nie) is soos kinders (sien die relevante besprekings by Malina \& Rohrbaugh 1992).

Dat mense kinders na Jesus toe gebring het om deur hom aangeraak te word, is histories gesien, hoogs waarskynlik. Gegewe die destydse wêreldbeeld; die talle vrese wat bestaan het oor kinders se welsyn, en Jesus se reputasie as wonderwerker, moes sodanige tonele dikwels afgespeel het.

"The picture is one of peasant women, many of whose babies would be dead within their first year, fearfully holding them out for Jesus to touch ... to protect them from or clear them of the evil

\footnotetext{
4 Matteus 11:16-9 // Lukas 7:31-35; Markus 10:15 // Lukas 18:17, Matteus 18:3; Markus 9:33-37 // Lukas 9:46-48, Matteus 18:1-5. Ander moontlike tekste wat relevant is, maar nie veel bydra tot hierdie vraag nie: Markus 5:21 vv (Jaïrus se 12jarige dogter); Matteus 21:15 (kinders wat in die tempel sing); Matteus 11:25-30 //

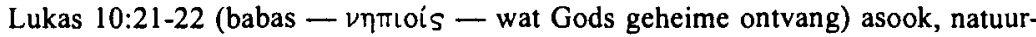
lik, die geboorteverhale oor Jesus self (Matt 2 en Luk 2).
} 
eye (this is the main malignancy from which parents have to protect their children in the Mediterranean) ..." (Malina \& Rohrbaugh 1992:243; kyk ook Theissen 1983:62-3).

Hier moet egter dadelik bygevoeg word dat Markus kinders aanwend as deel van sy tema oor die onbegryplikheid en veeleisendheid (bykans gevaarlikheid) van gehoorsaamheid aan God. Om 'n dissipel te wees is om "laaste, geringste, minste, nederig en weerloos" te wees (Mark 9:33). Lukas het ook iets van hierdie perspektief (Luk 9:46-48), en in hierdie tradisie sien ons waarskynlik die historiese Jesus in aksie.

Waarteen gewaak moet word, is dat 'n onhistoriese, revolusionêre Jesus voorgestel word wat radikaal sy tyd in alle opsigte vooruit was. As hy was, het sy dissipels òf nie verstaan wat hy wou doen nie, of baie doelbewus besluit om hom nie in hierdie (en in 'n hele paar ander sogenaamde revolusionêre) sieninge na te volg nie. Maar tegelykertyd sou, myns insiens, die hele poging tot historiese verstaan misluk as ons in "Jesus en die kinders" geen "teologie" sien nie. Jesus het ongetwyfeld sy dissipels opnuut en anders laat kyk na "dit wat die ou mense leer". Dit is net jammer dat ons tot vandag toe nog sukkel om erns te maak met Jesus se perspektief van vertrou op God en respek en liefde vir ander mense.

Verder het die Jesustradisies oor kinders ' $n$ rol in die kerkgeskiedenis gespeel, en, so deur die eeue heen, 'n bydrae gelewer tot_die verandering ten opsigte van die houdings en opvattings oor kinders.

\section{SAMEVATTING}

Die status van kinders was destyds 'n dubbelsinnige saak. In vele opsigte was dit nie veel anders as hoe slawe beskou was nie. Veral 'n pa kon met sy dogter maak wat hy wou: verkoop, verhuur en wat ook nog. Uiteraard was ouers baie lief vir hulle kinders. Ons moet net onthou hulle was lief vir kinders op 'n eerste-eeuse, Mediterreense wereld se manier.

Die eerste konklusie is dus die herbevestiging van "kulturele waarheid". Die uitleef van reg en verkeerd is onlosmaaklik verbonde aan 'n historiese konteks, 'n kultuur, 'n wêreldbeeld, 'n tyd en 'n plek. Dié insig noop ons om nie neer te kyk op diegene wat dinge anders doen nie, maar om te reflekteer oor wat en hoekom die beter en slegter maniere is om dinge doen, soos hoe om kinders groot te maak.

Dit is duidelik dat wanneer ons vandag probleme soos kindermishandeling, aborsie, familieprobleme, wangedrag van die jeug, en so meer wil aanspreek, stappe soos wetgewing en swaarder strawwe nie die werklike oorsake gaan of kan aanspreek nie. Wesentlik het ons te 
doen met waardestelsels en wêreldbeelde - dit is op daardie vlak wat daar eers verskille gemaak sal moet word.

Historiese ondersoeke stal, onder andere, die opsies vir mense se keuses voor ons uit. Dit is waartoe bygedra wou word met dié ondersoek: mense maak so met hulle kinders want so glo hulle en so sien hulle die werklikheid. Ons uitdaging is om die opsies en probleme wat voor óns lê te oorweeg in die lig van wat ons weet mense kan en kon doen.

Tweedens kan die belang van hierdie soort van ondersoek myns insiens nouliks oorskat word. Ons beweer graag dat ons iets begryp van die konteks van destyds, maar wat ons dikwels doen is om so te konsentreer op die sogenaamde "teologiese" en "religieuse" fasette, dat die werklikheid waarbinne en waarmee daardie geloof bestaan het, verdwyn.

Trouens, dis 'n vraag of ons werklik die "teologie" van daardie mense gaan begryp alvorens ons beter en dieper insig het in hulle kulturele en sosiale belewenisse: hulle emosies, waardes, perspektiewe, hulle syn is immers fundamenteel bepaal deur hulle kindwees - net soos ons s'n.

\section{Literatuurverwysings}

Archer, L J 1990. Her price is beyond rubies: The Jewish woman in GraecoRoman Palestine. Sheffield: Sheffield Academic Press.

Ariès, P 1996. Centuries of childhood. London: Random House.

Barr, J 1988. Abba isn't "daddy", Journal of Theological Studies 39: $28-47$.

Bimson, J J; Kane, J P; Paterson, J H \& Wiseman, D J 1985. New Bible atlas. Leicester: Inter-Varsity Press.

Bloch, M \& Adler, S M 1994. African children's play and the emergence of the sexual division of labor, in: J L Roopnarine, J E Johnson \& F H Hooper (eds), Children's play in diverse cultures, 148-78. Albany: State University of New York Press.

Botha, P J J 1992. Greco-Roman literacy as setting for New Testament writings, Neotestamen-tica 26: 195-215.

Botha, P J J 1993. Living voice and lifeless letters: reserve towards writing in the Greco-Roman world. Hervormde Teologiese Studies 49: 742-59.

Botha, P J J 1998. Die menigte rondom Jesus. Skrif en Kerk 19: 11-28.

Bouhdiba, A 1977. The child and the mother in Arab Muslim society, in: L C Brown \& N Itzkowitz (eds), Psychological dimensions of Near Eastern studies. Princeton: University Press.

Bradley, K R 1985. Child labour in the Roman world. Historical Reflections 12(2): 311-30. 
Broshi, M 1986. The diet of Palestine in the Roman period: introductory notes. Israel Museum Journal 5: 41-56.

Brown, P 1967. Augustine of Hippo. Berkeley: University of California Press.

Canaan, $T$ 1927. The child in Palestinian Arab superstition. Journal of the Palestine Oriental Society 7: 159-86.

Cook, P S 1978. Childrearing, culture and mental health: exploring an ethologicalevolutionary perspective in child psychiatry and preventive mental health with particular reference to two contrasting approaches to early childrearing. Medical Journal of Australia Special Supplement 2, 3-14.

Crenshaw, J L 1998. Education in ancient Israel: across the deadening silence. New York: Doubleday.

Demsky, A 1988. Writing in ancient Israel and early Judaism, in M J Mulder (ed), Mikra: text, translation, reading and interpretation of the Hebrew Bible in ancient Judaism and early Christianity, 1-20. Assen: Van Gorcum.

Derrett, J D M 1973. Jesus's audience: the social and psychological environment in which he worked. London: Darton, Longman \& Todd.

Detienne, M \& Vernant, J P (eds) 1989. The cuisine of sacrifice among the Greeks. Chicago: University of Chicago Press.

Eilberg-Schwartz, H 1980. The savage in Judaism: an anthropology of Israelite religion and ancient Judaism. Bloomington: Indiana University Press.

Etienne, R 1977. Ancient medical conscience and the life of children. Journal of Psychohistory 4: 131-61.

Faber van der Meulen, H E 1996. “Worden als een kind". Als welk kind? Hervormde Teolo-giese Studies 52(2): 351-75.

Falk, Z W 1974. Jewish private law, in S Safrai \& M Stern (eds), The Jewish people in the first century vol 1, 504-34. Philadelphia: Fortress.

Fiddes, N 1991. Meat: a natural symbol. London: Routledge.

Finley, M I 1981. The elderly in classical antiquity. Greece \& Rome 28: 156-71.

Forbes, R J 1967. Studies in ancient technology vol 3. Leiden: Brill.

Fuller, A H 1961. Buarij: portrait of a Lebanese Muslim village. Harvard Middle Eastern Monograph Series 6. Cambridge (M): Harvard University Press.

Garnsey, P 1986. Famine in the ancient Mediterranean. History Today 36: 24-30.

Golden, M 1988. Did the ancients care when their children died? Greece \& Rome 35: $152-63$.

Granqvist, H 1947. Birth and chlidhood among the Arabs: studies in a Muhammedan village in Palestine. Helsingfors: Söderström.

Hamel, G 1990. Poverty and charity in Roman Palestine, first three centuries $C E$ Berkeley: University of California Press.

Haines-Eitzen, K 1998. "Girls trained in beautiful writing": female scribes in Roman antiquity and early Christianity. Journal of Early Christian Studies 6(4): 629-46.

Hirschfeld, Y 1995. The Palestinian dwelling in the Roman-Byzantine period. Jerusalem: Franciscan Printing Press. 
Hunt, A S \& Edgar, C C 1932. Select Papyri 1 (Loeb 266). London: Heinemann.

Kelly, J N D 1975. Jerome: his life, writings and controversies. London: Duckworth.

Levy, A 1998. Bad timing. Biblical Archaeology Review 24(4): 18-23.

Lewis, N 1974. Papyrus in classical antiquity. Oxford: Clarendon.

Leyerle, B 1997. Appealing to children. Journal of Early Christian Studies 5(2): 243-70.

Lutfiyya, A M 1966. Baytin, a Jordanian village: a study of social institutions and social change in a folk community. The Hague: Mouton.

Malina, B J 1981. The New Testament world: insights from cultural anthropology. Atlanta: John Knox.

Malina, B J 1992. Is there a circum-Mediterranean person? Looking for stereotypes. Biblical Theology Bulletin 22: 66-87.

Malina, B J 1996. The social world of Jesus and the Gospels. London: Routledge.

Malina, B J \& Rohrbaugh, R L 1992. Social-science commentary on the synoptic gospels. Minneapolis: Fortress.

Pilch, J J 1993. "Beat his ribs while he is young" (Sir 30:12): a window on the Mediterranean world. Biblical Theology Bulletin 23: 101-13.

Redfield, R 1947. The folk society. American Journal of Sociology 52: 293-308.

Safrai, S 1976. House and family, in S Safrai \& M Stern (eds), The Jewish People in the first century: historical geography, political history, social, cultural and religious life and institutions, vol 2, 728-92. Philadelphia: Fortress.

Shahar, S 1990. Childhood in the Middle Ages. London: Routledge.

Sussman, M 1992. $s v$ "Sickness and disease". Anchor Bible Dictionary 6: 6-15.

Theissen, G 1983. The miracle stories of the early Christian tradition. Philadelphia: Fortress.

Veyne, $\mathrm{P}$ 1987. The Roman empire, in: Veyne, $\mathrm{P}$ (ed), A history of private life, vol 1: From pagan Rome to Byzantium, 5-233. Cambridge (Mass.): Belknap Press.

Weber, H-R 1979. Jesus and the children: Biblical resources for study and preaching. Geneva: World Council of Churches.

Whiting, B B \& Edwards, C P 1988. Children of different worlds: the formation of social behavior. Cambridge (M): Harvard University Press. 